\title{
ISTILAH KESEHATAN YANG BERKENAAN DENGAN COVID-19 YANG DIPILIH GENERASI MILENIAL
}

\author{
Exti Budihastuti \\ Badan Pengembangan dan Pembinaan Bahasa \\ e-mail: extibudihastuti@gmail
}

\begin{abstract}
As it is known that during this pandemic, the learning activities of millennials or students were limited to distance learning. With these limitations, we want to know how they choose the term health that is currently spreading, most of which come from absorption or foreign language translation (English) in everyday life. This study aims to determine the choices of millennials in using the term health in the era of the Covid-19 pandemic. Millennials who were respondents in this study were limited to only the age range of 18 to 20 years and were students. The method used in this research is a qualitative method with a descriptive approach. The data analysis steps used in this study were to analyze the questionnaire results from respondents using the Analysis Interactive Model from Miles and Huberman. The results showed that the diversity of the use of terms during the pandemic opened millennials' insights about the term health. The results of this study are expected to make Indonesian more loved by the Indonesian people, especially millennials.
\end{abstract}

Key words: health terms, Covid-19, millennials

\begin{abstract}
ABSTRAK
Seperti diketahui bahwa pada masa pandemi ini kegiatan belajar generasi milenial atau mahasiswa terbatas pada pembelajaran jarak jauh. Dengan keterbatasan tersebut ingin diketahui bagaimana mereka memilih istilah kesehatan yang kini tengah merebak yang sebagian besar berasal dari serapan atau terjemahan bahasa asing (bahasa Inggris) dalam kehidupan sehari-hari. Penelitian ini bertujuan mengetahui pilihan generasi milenial dalam mengunakan istilah kesehatan pada era pandemi Covid19. Generasi milenial yang menjadi responden pada penelitian ini dibatasi hanya pada rentang usia 18 sampai dengan 20 tahun dan berstatus mahasiswa. Metode yang digunakan dalam penelitian ini adalah metode kualitatif dengan pendekatan deskriptif. Langkah-langkah analisis data yang digunakan dalam penelitian ini adalah menganalisis hasil kuesioner dari responden menggunakan Analysis Interactive Model dari Miles dan Huberman. Hasil penelitian menunjukkan bahwa keberagaman penggunaan istilah pada masa pandemi membuka wawasan generasi milenial tentang istilah kesehatan. Hasil penelitian ini diharapkan dapat membuat bahasa Indonesia lebih dicintai masyarakat Indonesia, terutama generasi milenial.
\end{abstract}

Kata kunci: istilah kesehatan, Covid-19, generasi milenial

\section{PENDAHULUAN}

Sejak kasus pertama virus korona di Indonesia diumumkan oleh Presiden Jokowi pada awal bulan Maret 2020, kehidupan masyarakat Indonesia berubah. Kita seakan dipaksa untuk terbiasa mendengar dan menggunakan istilah baru di masa pandemi ini, terutama istilah yang berkaitan dengan kesehatan. Hal itu dikarenakan hampir setiap menit dalam 24 jam kita disuguhi berita tentang apa itu virus korona atau Covid-19, bagaimana penyebarannya, penularan, pencegahan, dan penanggulangan bagi yang terpapar, serta bagaimana penanganan bagi yang telah meninggal dunia akibat virus korona tersebut.

Satu hal yang amat penting pada masa pandemi ini adalah terganggunya kegiatan belajar-mengajar di kelas. Pada semua jenjang pendidikan, pemerintah mengeluarkan kebijakan untuk menghentikan kegiatan belajar-mengajar di kelas. Begitu juga para mahasiswa. Walau tergolong pada usia tinggi, jenjang pendidikan di kampus pun harus 
menggunakan pengajaran jarak jauh (PJJ) demi melaksanakan program pengajaran yang telah disusun.

Sebagai generasi milenial, para mahasiswa pun terkena imbas dari keadaan di era pandemi ini. Banyak istilah kesehatan yang didengar oleh mahasiswa, terutama yang berbahasa asing. Walaupun para mahasiswa tersebut diberikan materi tentang sikap positif berbahasa Indonesia, derasnya istilah asing tersebut memunculkan pertanyaan: apa istilah kesehatan yang mereka pilih pada saat pandemi Covid19 merebak yang sebagian besar istilah berasal dari serapan atau terjemahan dari bahasa asing (bahasa Inggris) dalam kehidupan mereka sehari-hari?

Tujuan dari penelitian ini adalah mengetahui pilihan generasi milenial dalam mengunakan istilah kesehatan pada era pandemi Covid-19. Harapannya adalah agar generasi milenial dapat mengenali istilah kesehatan dalam bahasa Indonesia, bukan bahasa asing sehingga bahasa Indonesia dapat lebih dicintai oleh masyarakat Indonesia, terutama generasi milenial.

\section{Istilah Kesehatan}

Dalam KBBI Edisi $V$ versi luring, kata “istilah" diartikan sebagai kata atau gabungan kata yang dengan cermat mengungkapkan makna konsep, proses, keadaan, atau sifat yang khas dalam bidang tertentu [1]. Istilah kesehatan yang digunakan pada masa pandemi Covid-19. Di antaranya adalah seperti pada Tabel 1.

Tabel 1 Istilah Kesehatan Berbahasa Asing dan Padanannya dalam Bahasa Indonesia

\begin{tabular}{cll}
\hline No. & Bahasa Asing & Bahasa Indonesia \\
\hline 1 & suspect & Terduga \\
2 & self-quarantine & karantina mandiri \\
3 & $\begin{array}{l}\text { cross } \\
\text { contamination }\end{array}$ & kontaminasi silang \\
4 & track record & rekam jejak \\
5 & airborne & (penularan) lintas \\
& (contagion) & udara \\
6 & face shield & pelindung muka \\
7 & thermo gun & termometer tembak \\
\hline
\end{tabular}

\begin{tabular}{lll}
\hline 8 & contact tracing & penelusuran kontak \\
9 & sharing pain & berbagi beban \\
10 & droplet & percikan \\
11 & epidemic & wabah \\
12 & rapid test & uji cepat \\
13 & swab test & uji usap \\
14 & hand sanitizer & penyanitasi tangan \\
15 & physical & pembatasan fisik \\
& distancing & \\
16 & social distancing & pembatasan sosial \\
17 & lockdown & karantina wilayah \\
18 & Covidnineteen & Kovid-sembilan belas \\
19 & coronavirus & virus Korona \\
20 & herd immunity & kekebalan kelompok \\
21 & local transmission & penularan lokal \\
\hline
\end{tabular}

Istilah kesehatan tersebut sengaja dipilih yang menggunakan bahasa asing dan padanannya dalam bahasa Indonesia. Istilah tersebut sudah diperkenalkan oleh sejumlah narasumber dan pejabat pemerintah melalui media masa cetak dan elektronik, baik yang menggunakan bahasa asing (bahasa Inggris), maupun yang menggunakan bahasa Indonesia sebagai padanan katanya. Para pejabat pemerintah atau yang dikenal dengan istilah Gugus Tugas memperkenalkan istilah kesehatan tersebut melalui media massa cetak dan elektronik. Sementara itu, Badan Pengembangan dan Pembinaan Bahasa melalui Instagramnya juga sudah menyosialisasikan istilah kesehatan tersebut. Media sosial digunakan oleh Badan Pengembangan dan Pembinaan Bahasa untuk menjangkau generasi milenial dalam penggunaan istilah kesehatan tersebut.

\section{Era Pandemi Covid-19}

Dalam KBBI Edisi V versi Luring, kata "era” berarti kurun waktu dalam sejarah; sejumlah tahun dalam jangka waktu antara beberapa peristiwa penting dalam sejarah; masa. Sementara itu, "pandemi" berarti wabah yang berjangkit serempak di mana-mana, meliputi daerah geografi yang luas [1]. Era pandemi Covid-19 adalah masa wabah penyakit yang berasal dari virus korona mulai berjangkit. 
Istilah pandemi selalu dikaitkan dengan istilah epidemi. Kedua istilah tersebut sangat identik atau berkaitan dengan penyebaran penyakit. Secara bahasa, epidemi diartikan penyakit menular yang berjangkit dengan cepat di daerah yang luas dan menimbulkan banyak korban [1]. Sementara, pandemi didefinisikan sebagai epidemi yang terjadi di seluruh dunia, atau di wilayah yang sangat luas, melintasi batas internasional dan memengaruhi sejumlah besar orang [2].

Di awal tahun 2020, dunia digemparkan dengan merebaknya virus baru, yaitu coronavirus jenis baru (SARS-CoV-2) dan penyakitnya disebut Coronavirus disease 2019 (Covid-19) [3]. Hingga kini para ahli kesehatan tengah berjuang keras menemukan obat untuk penyakit tersebut dan tidak ada yang tahu kapan era pandemi Covid-19 ini akan berakhir. Oleh karena itu, istilah yang muncul di masa pendemi ini perlu dicermati sebaikbaiknya oleh semua kalangan, terutama kalangan milenial.

\section{Generasi Milenial}

Menurut Kamus Besar Bahasa Indonesia (KBBI) Edisi $V$ versi luring kata "generasi" salah satunya berarti sekalian orang yang kira-kira sama waktu hidupnya; angkatan; turunan. Sementara itu, frasa "generasi milenial" adalah generasi yang lahir di antara tahun 1980-an dan 2000-an, yang kehidupannya tidak dapat lepas dari teknologi.

Wikipedia menyebut generasi milenial sebagai Gen Y atau Generasi Langgas, yaitu kelompok demografi setelah Generasi X (Gen-X). Tidak ada batas waktu yang pasti untuk awal dan akhir dari kelompok ini. Para ahli dan peneliti biasanya menggunakan awal 1980-an sebagai awal kelahiran kelompok ini dan pertengahan tahun 1990-an hingga awal 2000-an sebagai akhir kelahiran (Wikipedia, 2019). Itu artinya, seorang sudah bisa disebut termasuk generasi milenial menurut pengertian tersebut jika berusia di bawah 38 tahun.

Studi tentang generasi milenial di dunia, terutama di Amerika, telah dilakukan oleh Boston Consulting Group (BCG) bersama University of Berkley pada tahun 2011 dengan mengambil tema "American Millennials: Deciphering the Enigma Generation" dan Pew Research Center pada tahun 2010 yang merilis laporan riset dengan judul "Millennials: A Portrait of Generation Next." Hasilnya diketahui bahwa salah satu karakteristik generasi milenial adalah generasi milenial yang lebih tahu teknologi dibanding dengan orang tua mereka [4]. Dari beberapa batasan tentang generasi milenial, Kementerian Pemberdayaan Perempuan dan Perlindungan Perempuan dan BPS menyatakan bahwa di samping ada generasi sebelum generasi milenial, ada generasi setelah generasi milenial disebut Generasi Z yang lahir rentang tahun 2001sampai dengan 2010. Generasi Z ini merupakan peralihan dari Generasi Y atau generasi milenial pada saat teknologi sedang berkembang pesat. Namun, konsep generasi milenial Indonesia yang menyatakan bahwa penduduk Indonesia yang lahir antara tahun 1980-2000-lah yang dijadikan acuan untuk pengolahan data dalam penyajian selanjutnya [5].

Jadi, generasi milenial dalam penelitian ini maksudnya adalah golongan orang atau generasi yang lahir di antara tahun 1980-an dan 2000-an. Generasi milenial pada penelitian ini adalah juga dimaksud sebagai golongan masyarakat berintelektual tinggi yang kehidupannya tidak dapat lepas dari teknologi. Mahasiswa selalu dihubungkan dengan generasi muda yang menguasai teknologi dan membuat perubahan. Munculnya istilah-istilah kesehatan yang berhubungan dengan masa pandemi diharapkan dapat membuka wawasan generasi milenial agar lebih dapat memahami perubahan yang terjadi di masa pandemi ini. 


\section{METODOLOGI}

Metode yang digunakan dalam penelitian ini adalah metode kualitatif dengan pendekatan deskriptif. Langkahlangkah analisis data yang digunakan dalam penelitian ini adalah menganalisis hasil kuesioner dari responden menggunakan Analysis Interactive Model dari Miles dan Huberman. Huberman yang membagi langkahlangkah dalam kegiatan analisis data dengan beberapa bagian, yaitu pengumpulan data (data collection), reduksi data (data reduction), penyajian data (data display), dan penarikan kesimpulan atau verifikasi (conclution).

Pengumpulan data dimulai dari mengumpulkan responden penelitian ini, yaitu 99 mahasiswa semester dua sebuah perguruan tinggi kedinasan yang berusia 18 sampai 20 tahun sebagai generasi milenial. Sebenarnya ada sebanyak 114 kuesioner yang disebar, tetapi sampai batas waktu yang ditetapkan hanya 99 data yang terkumpul. Lalu, mereduksi data dengan memisahkan pilihan istilah kesehatan berbahasa asing (bahasa Inggris) dan berbahasa Indonesia. Penyajian data menggunakan tabel dan grafik. Kuesioner yang digunakan untuk pengumpulan data diisi oleh responden pada tanggal 3 Agustus 2020 melalui Google Form.

\section{HASIL DAN PEMBAHASAN}

Tabel 2 Jumlah Responden Berdasarkan Umur dan Jenis Kelamin

\begin{tabular}{lccc}
\hline Umur & $\begin{array}{c}\text { Laki- } \\
\text { Laki }\end{array}$ & $\begin{array}{c}\text { Peremp } \\
\text { uan }\end{array}$ & Jumlah \\
\hline 18 Tahun & 9 & 5 & 14 \\
19 Tahun & 34 & 21 & 55 \\
20 Tahun & 20 & 9 & 29 \\
Di atas 20 & 0 & 1 & 1 \\
Tahun & $\mathbf{6 3}$ & $\mathbf{3 6}$ & $\mathbf{9 9}$ \\
Jumlah & & & \\
\hline
\end{tabular}

Pada Tabel 2 diketahui bahwa jika dilihat berdasarkan umur, sebagian besar responden adalah berusia 19 tahun, yaitu berjumlah 55 orang. Sementara itu, berdasarkan jenis kelamin, mayoritas responden adalah laki-laki, yaitu sebanyak 63 orang dari 99 jumlah total responden.

Namun demikian, jika kita merujuk pada hasil penelitian yang dilakukan oleh Kementerian Pemberdayaan Perempuan dan Perlindungan Perempuan bekerja sama dengan Badan Pusat Statistik yang menyatakan bahwa

"Jika ditelaah lebih jauh dari sisi gender, angka melek huruf generasi milenial antara laki-laki dan perempuan tidak terlalu jauh atau dapat dikatakan sudah sama dengan angka mendekati 100 persen. Adanya perubahan angka melek huruf dari generasi ke generasi menujukkan bahwa telah ada perbaikan kualitas pendidikan dan persamaan gender di Indonesia " [5],

keberadaan jenis kelamin dalam penelitian ini diabaikan. Jadi, data jenis kelamin digunakan hanya untuk mendeskripsikan jumlah responden.

Usia responden sembilan belas tahun menjadi usia yang paling banyak menyumbang angka pemilihan istilah asing. Seperti kita ketahui bahwa idealnya berusia 18 atau 19 tahun. Ketentuan usia itu berdasarkan usia ideal siswa di sekolah lanjutan atas. Jika berusia lebih dari 19 tahun diasumsikan responden tersebut sudah mempunyai pengalaman lain sebelum memasuki perkuliahan yang sekarang. Ini berarti responden tersebut seharusnya mempunyai lebih banyak wawasan dalam memilih kosakata. 
Grafik 1. Pilihan Istilah Kesehatan Berbahasa Inggris

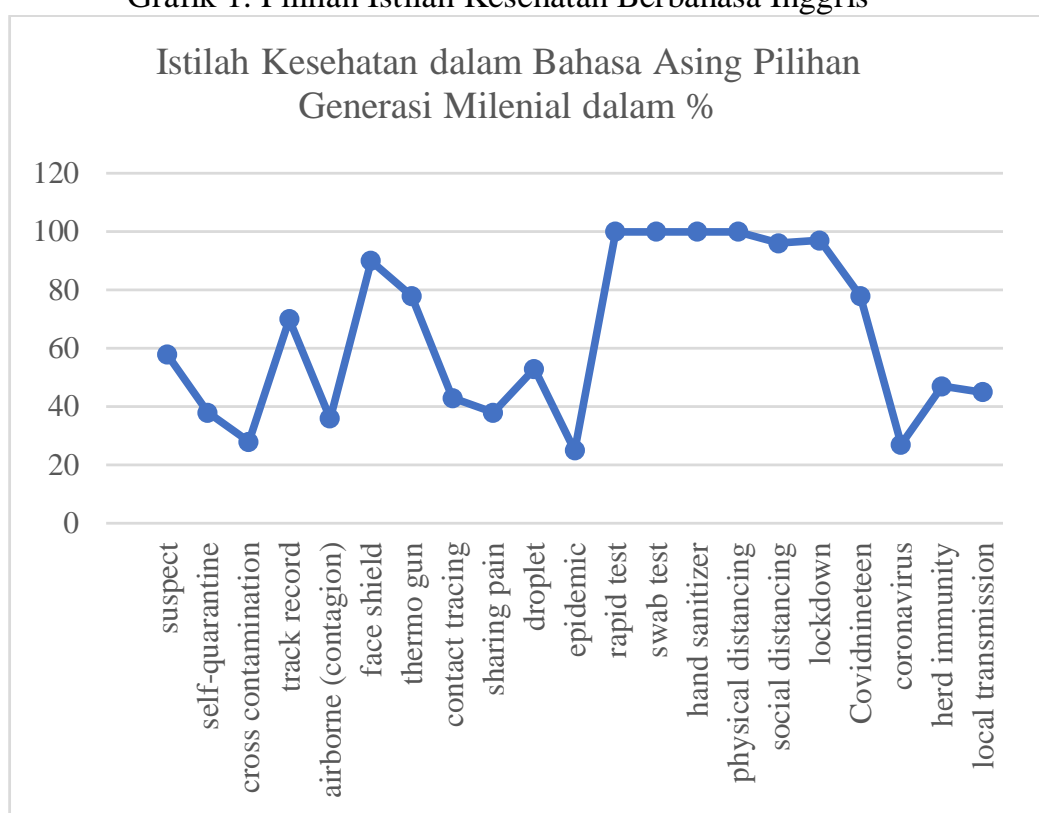

Dari Grafik 1 diketahui bahwa

1. Istilah rapid test, swab test, hand sanitizer, dan physical distancing dipilih oleh semua responden atau seratus persen.

2. Istilah face shield, social distancing, dan lockdown dipilih oleh hampir semua responden atau 90--100 persen.

3. Istilah covidnineteen, droplet, track record, dan suspect dipilih oleh lebih dari separuh jumlah responden atau lebih dari lima puluh persen.

4. Ada 11 dari 21 istilah kesehatan berbahasa Inggris yang dipilih oleh responden dalam kehidupan seharihari. Hal ini menunjukkan kecenderungan generasi milenial yang lebih suka menggunakan istilah asing.

Menurut Ivan Lanin, salah satu penyebab salah kaprah pada masyarakat kita adalah keinginan untuk menggantikan suatu kata bahasa Indonesia dengan bahasa asing karena dirasa lebih keren. Lanin menyebutkan juga bahwa gejala seperti itu mungkin sesuai dengan apa yang oleh Hipyan Nopri-penerjemah bahasa InggrisIndonesia-disebut dengan xenoglosofilia, yaitu suatu kecenderungan menggunakan kata-kata aneh atau asing terutama dengan cara yang tidak wajar [6].

Walaupun kata-kata yang terdapat pada istilah kesehatan itu (rapid test, swab test, hand sanitizer, dan physical distancing) bukan kata-kata aneh, nyatanya dipilih oleh semua responden. Mungkin hal itu disebabkan pelafalannya lebih pendek daripada istilah dalam bahasa Indonesia. Mungkin juga, seperti yang dikatakan Ivan Lanin, merasa lebih keren jika menggunakan istilah asing.

Masih dalam buku yang sama, Nur Aji mengatakan bahwa orang Indonesia cenderung xenoglosofilia, lebih senang menggunakan bahasa asing, khususnya Inggris, daripada bahasa ibunya, bahasa Indonesia, yang tidak pada tempatnya [6]. Tidak pada tempatnya di sini berarti penggunaan bahasa asing itu tidak perlu karena sudah ada padanannya dalam bahasa Indonesia atau dalam konteksnya memang tidak perlu berbahasa asing karena tidak ada yang berkepentingan dengan bahasa asing tersebut.

Menurut Arisandy, bahasa Indonesia sangat rentan dipengaruhi bahasa luar yang faktor utamanya merupakan generasi milenial. Kemunculan generasi milenial membuat bahasa Indonesia, seperti ketinggalan zaman atau kuno 
karena di era milenial seseorang lebih tertarik berbahasa Inggris agar kelihatan, seperti bule dan kalangan terpelajar [7]. Oleh karena itulah perlu ditanamkan sikap positif berbahasa Indonesia pada generasi milenial.

Menurut I Wayan Pastika, pengaruh bahasa asing tidak dapat dihindarkan dalam hubungan langsung antarbangsa dan antarbahasa karena sebuah bahasa yang masih berkembang memerlukan tambahan kosakata agar menjadi bahasa yang mantap secara linguistik, sosial dan politik [8]. Oleh karena itu, penggunaan bahasa asing harus disikapi dengan bijak.

Grafik 2 Pilihan Istilah Kesehatan Berbahasa Indonesia

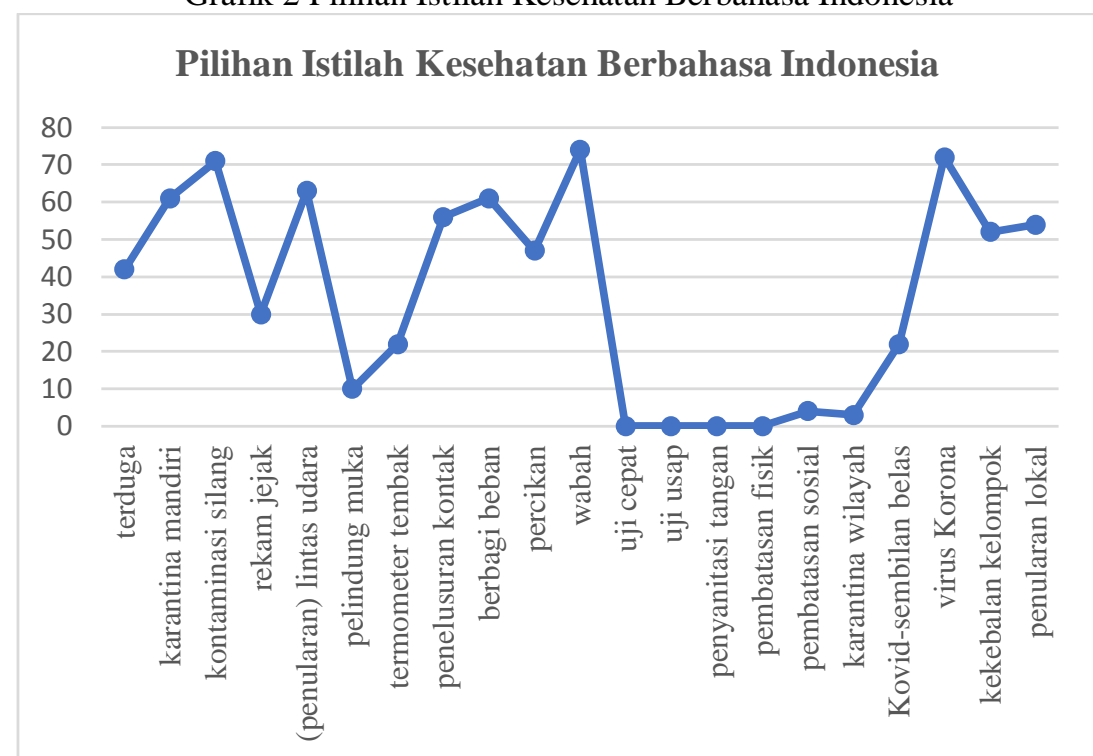

Dari Grafik 2 diketahui bahwa

1. Istilah uji cepat, uji usap, penyanitasi tangan, dan pembatasan fisik sama sekali tidak dipilih atau nol persen.

2. Istilah pelindung muka, pembatasan sosial, dan karantina wilayah hanya kurang dari sepuluh persen pemilihannya.

3. Istilah karantina mandiri, kontaminasi silang, (penularan) lintas udara, penelusuran kontak, berbagi beban, wabah, virus korona, kekebalan kelompok, dan penularan lokal dipilih oleh lebih dari separuh jumlah responden pemilih bahasa Indonesia atau di atas lima puluh persen.

Pemilihan istilah lebih dari separuh jumlah responden pemilih bahasa Indonesia atau di atas lima puluh persen diasumsikan bahwa responden telah mempelajari salah satu kewajiban mahasiswa terhadap Bahasa Indonesia, yaitu mempunyai sikap positif berbahasa Indonesia. Terlepas dari persoalan suka atau tidak suka menggunakan istilah Kesehatan dalam Bahasa Indonesia. Sikap seperti itulah yang dapat mendorong mahasiswa atau generasi milenial lain untuk lebih memilih istilah kesehatan dalam bahasa Indonesia sebagai wujud kecintaan terhadap bahasa Indonesia.

Menurut Rahaningmas, di era globalisasi ini, maraknya penyalahgunaan bahasa yang serampangan dengan cara mencampur-campur bahasa Indonesia dengan bahasa asing ataupun bahasa gaul membuat kita resah terhadap nasib perkembangan dan keberadaan bahasa Indonesia. Generasi muda lebih cenderung sering menggunakan gaul daripada menggunakan bahasa Indonesia yang baik dan benar [9]. Akan tetapi, kecenderungan menggunakan bahasa gaul itu sedikit demi sedikit akan luntur jika generasi muda itu mengingat 
kembali materi yang diberikan di tempat perkuliahan.

Sikap berbahasa Indonesia mahasiswa dirumuskan sesuai dengan rumusan mengenai sikap bahasa menurut Garvin \& Mathiot, yang merupakan ciri-ciri sikap yang positif terhadap bahasa [10]. Ciri-ciri sikap bahasa tersebut dirumuskan sebagai berikut:

1. Kesetiaan bahasa (language loyalty) yang mendorong masyarakat suatu bahasa mempertahankan bahasanya dan apabila perlu mencegah adanya pengaruh bahasa lain.

2. Kebanggaan bahasa (language pride) yang mendorong orang mengembangkan bahasanya dan menggunakannya sebagai lambang identitas dan kesatuan masyarakat.

3. Kesadaran adanya norma bahasa (awareness of the norm) yang mendorong orang menggunakan bahasanya dengan cermat dan santun merupakan faktor yang sangat besar pengaruhnya terhadap perbuatan yaitu kegiatan menggunakan bahasa (language use).

Generasi milenial yang menyadari ciriciri sikap positip berbahasa itu diharapkan mampu membedakan waktu dan tempat mereka menggunakan bahasa, baik bahasa asing (Inggris), maupun bahasa Indonesia. Ketika merebak istilah kesehatan berbahasa asing, dengan sadar generasi milenial tersebut akan memilihnya secara bijak.

\section{KESIMPULAN}

Dari 21 istilah kesehatan yang dipilih oleh 99 responden, ada 64 persen atau 1.335 istilah kesehatan berbahasa asing yang dipilih oleh responden dan 36 persen atau 744 istilah kesehatan berbahasa Indonesia yang dipilih oleh 99 responden. Artinya, secara kuantitatif generasi milenial lebih banyak memilih istilah kesehatan berbahasa asing (Inggris).
Istilah rapid test, swab test, hand sanitizer, dan physical distancing dipilih oleh semua responden atau seratus persen serta istilah uji cepat, uji usap, penyanitasi tangan, dan pembatasan fisik sama sekali tidak dipilih atau nol persen. Hal ini menunjukkan bahwa pemasyarakatan padanan kata berbahasa asing tersebut melalui media massa cetak dan elektronik yang dilakukan oleh para pemangku kepentingan, dan juga oleh Badan Pengembangan dan Pembinaan Bahasa belum sepenuhnya dikatakan berhasil.

Hasil penelitian menunjukkan bahwa keberagaman penggunaan istilah pada masa pandemi membuka wawasan generasi milenial tentang istilah kesehatan terutama bagi generasi milenial yang mendapatkan materi tentang sikap positif berbahasa Hasil penelitian ini diharapkan dapat membuat bahasa Indonesia lebih dicintai masyarakat Indonesia, terutama generasi milenial.

\section{DAFTAR PUSTAKA}

[1] Badan Pengembangan dan Pembinaan, Kamus Besar Bahasa Indonesia versi Luring, V. Jakarta: Kementerian Pendidikan dan Kebudayaan, 2019.

[2] I. M. Agung, "Memahami Pandemi Covid-19 Dalam Perspektif Psikologi Sosial,” PsikobuletinBuletin Ilm. Psikol., vol. 1, no. 2, hal. 68-84, 2020, [Daring]. Tersedia pada: http://ejournal.uin-

suska.ac.id/index.php/Psikobuletin/ article/view/9616/5058.

[3] Yuliana, "Corona Virus Disease (Covid-19); Sebuah Tinjauan Literatur," Wellness and Healthy Magazine, hal. 187--192, 2020.

[4] CNN INdonesia, "Generasi Millenial dan Karakteristiknya," 2019. 
[5] K. P. P. dan P. Anak, Statistik Gender Tematik: Profil Generasi Milenial Indonesia. Jakarta: Kementerian Pemberdayaan Perempuan dan Perlindungan Anak, 2018.

[6] I. Lanin, Xenoglosofilia: Kenapa Harus Nginggris? Jakarta: Gramedia, 2019.

[7] D. Arisandy, D. P. Rizkika, dan T. D. Astika, "Eksistensi Bahasa Indonesia Pada Generasi Milenial Di Era Industri 4.0,” Pendidik. Bhs. dan Sastra Indones., vol. 3, no. 2, hal. 247-251, 2019, [Daring]. Tersedia pada: garuda.ristekbrin.go.id.

[8] I. Pastika, "Pengaruh Bahasa Asing terhadap Bahasa Indonesia dan Bahasa Daerah: Peluang atau Ancaman?,” J. Kaji. Bali (Journal Bali Stud., vol. 2, no. 2, hal. 141164, 2012.

[9] S. A. Rahaningmas, S. Wahyuni, dan M. Mahendra, "Penggunaan Bahasa Indonesia Di Kalangan Generasi Milenial,” 2019, doi: 10.31227/osf.io/r6wku.

[10]A. dan L. A. Chaer, Sosiolinguistik: Perkenalan Awal, Edisi Revi. Rineka Cipta, 2010. 